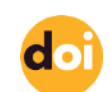

http://doi.org/10.22282/ojrs.2021.78

\title{
AN INVESTIGATION OF RECREATION IN TERMS OF ISLAMIC RELIGION
}

\author{
${ }^{1}$ Cengiz BAYKARA, ${ }^{2}$ Songül BAYKARA, ${ }^{3}$ Cihat KISA, ${ }^{4}$ Çetin YAMAN \\ ${ }^{1}$ Sakarya University of Applied Sciences, Graduate Education Institute, Physical Education and Sports Teaching Department, \\ Sakarya, TURKEY \\ ${ }^{2}$ Sakarya University of Applied Sciences, Graduate Education Institute, Recreation Department, Sakarya, TURKEY \\ ${ }^{3}$ Dokuz Eylül University İzmir, TURKEY \\ ${ }^{4}$ Sakarya University of Applied Sciences, Faculty of Sports Science, Sakarya, TURKEY
}

\begin{abstract}
All religions aim to make people socially, emotionally, mentally, physically, and spiritually well, and in Islam, it advises people to be healthy and happy both in this world and in the hereafter. We see the proofs of this in the Quran and Sunnah, which are the main sources of Islam. The study is made by the archive and is limited to the available resources. The sources define health as the state of well-being of a person in all dimensions. Based on this definition, it can be said that Islam aims at the well-being of a person in all dimensions. Apart from the time devoted to working, a person always needs to stop, rest, and spend his or her favorite activities in all the hustle and bustle of life. Thus, since the individual will be more rested both spiritually and physically, he/she will have done the tasks he/she needs to do better. Islam expresses that a person should allocate time in a balanced way for both this world and the life of the hereafter and do what is necessary. Islam gives importance to the use and management of one's time. Participation in sports activities affects individuals positively in many ways. Sports activities that have this effect, Hz. Muhammad (s.a.v) took part in his whole life and recommended certain sports branches to his companions. The Prophet who encouraged children to play and sometimes accompanied their games, Hz. Muhammad (s.a.v) set an example for the companions as well. In this study, sports, recreation, recreation, and sports according to Islam are emphasized. As recreation, which is a part of community life, improves the quality of life of people, it has been considered important as a study subject. As a continuation of this study, it is proposed to examine recreation in terms of theology, that is to reveal the importance of recreation in terms of other religions.
\end{abstract}

Key Words: Recreation, Religion, Sport, Game, Time 


\section{INTRODUCTION}

Islam aims at the happiness of the world and the hereafter in terms of the health of the human soul and body. For this to happen, religion aims to raise individuals who are virtuous and do not compromise moral values, who act by following per under the wishes of the creator, adhere to the main rules of religion and by following per under the expectations of the society, by taking into account the innate characteristics. Human qualities are needed in our age and the qualities sought in people that religious education aims to train; To be good in terms of mental and physical health, to be beneficial to yourself and the environment, to be virtuous. For this, he must appreciate the time given to him by Allah, and he must be able to manage his working, recreational, and resting areas well. In our study, sports, recreation, recreation, and sports according to Islam are emphasized. Because recreation, which is a part of community life, can increase the quality of life of people.

\section{The Sense of Time}

When asked what is the most important thing in life, Edison replied "Time" (Yaman, Türkmen, Hergüner, 2012, p. 165). Since ancient times, the concept of "time" has attracted the attention of almost all philosophers and has gained an important place in their philosophies and perspectives on life. Many questions and answers were sought about time in the fields of philosophy and logic. What is time, how is it perceived, is it mentally valid or not, and many more questions are just a few of them. Many debates in the philosophy of religion and theology can be associated with the sense of time, also in relation to the attributes or existence of the creator. Along with these, fate - fatality subject, moral responsibility, free will and other similar issues are directly or indirectly related to the relationship of man with "time" in terms of Islam and some other religions (Hardal, 2012, p. 1).

It is described that an old wise S.t. Augistine "I know what time is unless I am asked what time is; but when asked, I don't know." (Nobert, 2000, p: 12). It is not possible to make a single definition of time that is valid for everyone (Atay, 1974, p. 74). Therefore, the sense of time does not have a complete and precise definition. For this reason, time has always been a very important concept for humanity since the day of human existence. The society that manages and uses time according to the understanding of business life, social relations, 
entertainment and provides more development than other societies. There are differences between each person's and every society's understanding of time. Religious understanding, attitudes and practices are also important factors in the formation of these views. Lack of time or personal shortage is becoming one of the most important problems of the 21st century. Therefore, it is important to use time efficiently. (Ayylldı, 2015).

\section{Time Management}

The sense of time management, which is a very new concept, emerged in the 1970s. In the early 1980s, time is seen as a resource to be managed by managers. (Topal, 2009). Time management originated in Denmark. The aim is to help managers with heavy workload organize their time better. For this purpose, it has spread around the world as an educational tool. (Akatay, 2003). Today, it has become one of the most important factors for success, especially in professional working life (Koch, 1998, p.147). Physical (real) time has the same function in nature for all living things. Physical (real) time cannot be managed because it flows at the pace determined by its own rules. Expressing that the sense of time management is misused, Time magazine manager Pearson, regarding the sense of time management; "We cannot manage time, we can only manage ourselves according to time." (Josephs, 1996, p. 8). While the earth continues to rotate around its axis and the sun, the movements of the hour and minute hands are beyond the control of the day and night, seasons and years. The value of time given equally to all depends solely on its use. A finite and scarce portion of time is expressed as biological time. Biological time cannot be collected like money, stored like raw materials, and used when needed (Yllmaz \& Aslan, 2002). Therefore, the only thing that can be done is to make the best use of time (Karsl1, 2004; Scoot, 1997). The problem is not the management of the clock, but the individual's self-management in time (Mackenzie, 1989, p.15).

Regarding time management, Hall said, "People cannot manage time. However, they make better use of their time "(Deniz, 1996, p. 110). It is necessary to determine and plan which job will be completed in how long. (Topal, 2009). In short, time management is to reduce the time required to complete the job (Amount, 2003, p. 13).

The perception and use of time varies from culture to culture, society to society. In a retrospective traditional society, time is seen as a very flexible and inexhaustible resource. For 
example, most of the economic activities in rural areas are seasonal depending on the socioeconomic and cultural structure of the region. Individuals work in the summer and spend the winter. Therefore, in traditional (agricultural) society, time is often expressed in terms of seasons. With all the mechanization of modern (industrial) society, the only problem seems to be time constraints. Therefore, time is seen as a mechanical process in developed societies. Time is divided into minutes and seconds, and certain tasks are deemed necessary and planned to be performed within a certain period of time (Karsl1, 2004). Time management according to another definition; It is also defined as determining the needs through planning, programming and listing, determining the necessary targets to meet these needs, determining the priority tasks and being consistent over time (Smythe \& Robertson, 1999, p. 333). Time management means efficient use of resources in terms of time (Yllmaz \& Aslan, 2002). The more work and activity people do over a period of time, the more time they manage. When we look at time management from this point of view, it is the management of activities in which we occupy ourselves over time (Tengilimoğlu, Tutar, Altınöz, Öztürk, Başpınar, \& Erdönmez, 2003, p.5). Time management is the management of activities. It is that time will be occupied and time will be successfully allocated to activity areas. In short, it is self-governing over time (Tutar, 2007, p.18). Personal process is one of the most important points in time management (Haynes, 1999, p. 16). There is coordination between personal energy levels and activities (Balc1, 1990). As can be seen, many definitions regarding time management are encountered. Looking at the definitions, it is stated how it should be evaluated in the management of time and which ways to focus on doing this.

\section{The Sense of Religion}

Religion has many meanings in Arabic such as attitude, judgment, reward, obedience and responsibility. In Latin, religion is used as the word "religio". This word means attachment, loyalty intertwined with congregation and reverence towards God. There is not only one definition of religion, but more than one definition from various angles. Jocheim Wach defines religion briefly as "the experience of the sacred in social life". Another scientist, Parsons, expresses religion as "the understanding developed and realized about what is desirable or not depending on the place of man in the universe, the relationship of man with others, his environment and relations with other people". Finally, Eliade says that religion is "the 
manifestation of the experience arising from the relationship between the transcendent being and the person who believes in it, in the life of the believer" (Arslantürk, 2014, pp. 26-29).

In the view of Islam, religion is "founded by Allah and its members in the world and the hereafter; They are a path and institutions composed of belief and deeds that lead to happiness and peace. " (Akseki, 1960, p.7). In the Quran, the word religion means rule, obedience, worship, tawhid, Islam, sharia, borders, customs, punishments, calculations, countries (Tümer and Küçük 1997, pp. 1-4). According to the Islamic scholars; It is defined as all divine orders and prohibitions sent by Allah through the prophets that will enable people to find the right and right path with their own mind and will in order to ensure the happiness of people in the world and the hereafter (Bilmen, 1972, pp. 42-46).

Religion, which is as old as humanity, is one of the social institutions that affect the behavior of individuals as well as regulating the social structure. Studies conducted are one of the most important factors that contribute to the coexistence of individuals who make up the society of religion (Han 1989; Nebi, 1991).

In short, according to all these definitions, religion is an institution that provides a lifestyle to people sociologically and gathers people around a certain world view, evaluation and lifestyle. It is expressed as connecting to the creator, listening and believing in something and acting voluntarily accordingly (Arslantürk, 2014, pp. 26-29).

\section{The Sense of Time in Islam}

The sense of time is always a sense that is searched by people and answers are sought by asking what it is. The word time, which is an Arabic word, "zemen" and "time" is a name used to indicate the shortage and abundance of time (Efendi, 1755-1820, p. 5383). Time is not included in the Quran but terms expressing the characteristics of time are included. Literally, the word "time" means "time that is long or short" (Canan, 2008, p. 24). However, the word time is included in the hadiths. For example, the hadith "There will come a time when people will not care whether what they take is halal or haram" is one of the examples to be given on this subject (Bukhari, Buy'ü, 7; Nasai, Buyu, 2). ${ }^{1}$ Apart from that, many different definitions have been made about the word time. The religion of Islam informs people about how useful

${ }^{1}$ Diyanet İşleri Başkanlığı (DİB), https://dergi.diyanet.gov.tr/ (E. T. 14 Aralık 2020) 
and productive time is spent by people. The sense of time in Islam can be classified in two ways: the sense of time according to the Quran and the sense of time according to the Hadiths.

\section{The Sense of Time in Verses}

Time is mentioned in many verses in the Quran. The word time is not mentioned as a word in the Quran (Canan, 2008, p.24). The concepts used to express the word "Time" in the Quran cover a very wide area. If the words that can be time expressions in the Quran are expressed as a time line, the words meaning short and long time periods in the Quran can be classified into two categories.

\section{Words Meaning Short Time Periods in the Quran}

The word moment refers to the smallest unit of time. The words closest to the sense of moment in terms of duration and their meanings are given below.

a. Vakt: It means the end of a determined time for the work, the moment, time, period, season

b. Bağteten: The occurrence of something suddenly, abruptly, blindly

c. Lemhu'l-basar: The eye quickly looking at something else, the star shining, the lightning fast flashing to create a glow

d. Saat: Part of time, doomsday

e. Leyl: Night is the time period before the day

f. Fecr: Splitting, splitting something into two parts, giving way to water, the dawn before sunrise

g. Subh: The first moments of the day when the sun begins to turn red on the horizon

h. Duha: A certain period of time, the length of the sun, the spread of the sun

i. Nehar: When the sun's rays spread

j. Yevm: The period between sunrise and sunset means any time period today.

\section{Words That Mean Long Time Period}

a. SSehr: Time peiod starting with the appearance of the crescent

b. Sene: Year 
c. Hin: To approach the time, to come to the time

d. Ahkab: Year, years, long time

e. Asr: A period of a hundred years, filling in the afternoon, extracting the juice, squeezing, period, cycle, afternoon

f. Dehr: For a long time, the duration of the realm from the first creation until it ends

g. Ebed: Absolute time, time, forever

i. Sermed: Continuous continuity means the continuation of day and night (cited in Pasl1, 2019, pp. 13-63)

As can be seen, it is seen that there are many verses about time in the Quran and the Quran emphasizes the importance of time. Some of these verses are about Muslims' effective use of time in order to make him "aware of the time". For example, the main objectives of fard prayers include making the individual the habit of dividing and programming his / her daily time, determining the times of sleep, resting, visiting, and chatting, and planning well. (Canan, 2008, p.33). In the Surah Asr, "Asr, I swear that man is really in a waste. But those who believe and do useful deeds for the good world and the hereafter, those who advise each other the right and advise patience are different". ${ }^{2}$ Verses are interpreted as follows. At the entrance of the Surah, attention was drawn to the place and importance of time in human life by taking an oath of time. Almighty Allah emphasized the importance of time by swearing on this concept; $\mathrm{He}$ reminded his servant that a person who does not evaluate him well will end as "disappointment" as he expressed in the second verse. Here, "waste" means the torment of the hereafter. The person who has wasted time and life is in the biggest mistake. Surah Asr "states that those who do not appreciate the century, that is, the age, and those who do not know the value of time will not have a good ending, and it points out to a social reality, the importance of social circumcisions and social rules". ${ }^{3}$ The Hadith "There are two blessings that most people are deceived by: health and leisure" 4 is actually a commentary of the surah Asr. In addition to the evaluation of time, the Surah establishes a relationship with health and leisure time. There

\footnotetext{
${ }^{2}$ Kur'ân Yolu Meâli, Hazırlayanlar. Hayrettin Karaman - Mustafa Çağrıcı- İbrahim Kafi Dönmez- Sadrettin Gümüş (Ankara: Diyanet İşleri Başkanlığı Yayınları, 2018), el-Asr 103/1-3.

3 Diyanet İşleri Başkanlığı (DỉB),” Diyanet Tefsir” el-Asr 103/1-3. (Erişim 15 Aralık 2020)

${ }^{4}$ Diyanet İşleri Başkanlığı (DİB), "Diyanet webdosya". (Erişim 14 Aralık 2020)
} 
are some suggestions in the hadith on how to use time wisely, how to develop habits, and how to do this within the framework of Islamic rules and principles in all areas and every point of life. It is seen that Muslims have the responsibility to use their time effectively and efficiently and to fulfill the behaviors required by their religion and holiness (Karaküçük, 2019, p.48).

The 67th verse of Surah Yunus is another verse where important clues can be found regarding resting and leisure time. In this verse, Almighty Allah (c.c) "It is He who bestowed on you the night so that you may rest in it, and the day so that you may see (your deeds). Undoubtedly, there are lessons in this for a community that knows how to listen. " The explanation of the verse is made as follows. "Life passes between night and day; people both rest and work to live. Generally, the darkness of the night is more suitable for relaxation and the light of the day is more suitable for working. Here is the true god of the people, who makes this process in which they spend their lives; It is Allah who creates and makes all time useful, with its dark nights of rest and bright days of work. Those who know how to listen and reflect on the evidences revealed by Allah in his enlightening speech understand the meaning of this system and that the power that establishes it is unique and without partners". ${ }^{5}$

\section{The Sense of Time in Hadiths}

In the following hadits of $\mathrm{Hz}$. Muhammad (s.a.v), the process of man from birth to death is described. "Know the value of five things before five things; Your youth before old age, your health before you get sick, your wealth before poverty comes, your free time before busy, and your life before you die ". ${ }^{6}$ In fact, the hadith implies that people do something they care about in life and ensure that they obtain the key to a "quality life". Since the hadith is very meaningful and enlightening, it makes people think in terms of its meaning and it means a lot with few words (Karaküçük, 2019, p.96). Expressing time in whole numbers is seen in some hadiths: The Messenger of Allah (s.a.v) said "Allah wrote the quantities of the creatures fifty thousand years before creating the heaven and the earth, while his throne was on the water ".? "The Messenger of Allah (s.a.v) said," There are forty between two blowing walls! " There upon, those asked, "Oh! Abu Huraira, forty days? He said, "I can't say anything". ${ }^{8}$ In a hadith

\footnotetext{
${ }^{5}$ Diyanet İşleri Başkanlığı (DİB),” Diyanet Tefsir" Yunus 10/67.

${ }^{6}$ Diyanet İşleri Başkanlığı (DİB), "hadislerleislam". (Erişism 14 Aralık 2020)

${ }^{7}$ Muhaddis, "muhaddis.org". (Erişim 14 Aralık 2020)

${ }^{8}$ Diyanet İşleri Başkanlığı (DİB), "Diyanet webdosya"
} 
it is stated, "Time becomes unprofitable for years and months, as many months, as weeks, as manu weeks, as days, the sun is up for hours; doomsday will not come until the hour is shortened as dry wood burns on fire". ${ }^{9}$ Apart from that, there are hadiths regarding time.

\section{The Sense of Free Time}

Free time, which is used as "free time" in the literature, can be used in the same sense as "free time". Aristotle examines the most important element of free time by looking at what the individual is "engaged in", Brightbill emphasizes the time used according to personal decisions and preferences (Torkildsen, 1992, pp. 25-28). Apart from personal compulsory behavior, free time to live according to the social structure they live in and to take them to a new level; It can be defined as the period that they can evaluate with their free will. (Mansuroğlu, 2002, p.53)

Free time was first defined in Veblen's "Leisure Class Theory". This definition has lost its validity today. The reason for this is only because it refers to the groups that own the means of production, consume and use their returns. In today's use of free time, it refers to the time left over from working, mostly by the working population. Free time saves individuals from work difficulties and offers individuals relaxation opportunities (Omay, (2008). Free time research was first conducted in the United States in the 1950s to determine the relationship between socio-economic structure and individual participation in activities. In the following years, while ethnic minorities and concepts such as politics, race, nationality, elderly population, and lifestyle were evaluated, all concepts were evaluated together since the 1990s (Lee, Scott, \& Floyd, 2001). As a reason for the decrease in working hours as a result of industrialization, developments such as free time and leisure time increase have occurred. As a result of these developments, leisure time, which does not contain a positive meaning, is associated with passive, insatiable and uncreative entertainment (Torkildsen, 2005, p.48). There is evidence that free time can improve physical, social, emotional and cognitive health (through adaptation, rehabilitation, and beyond) through protection, prevention, coping and beyond (through adaptation, rehabilitation and beyond), even if not meaningfully. The fact that the feeling of freedom accompanies free time is the only situation in which an individual can be himself and everything he does is considered meaningful. (Caldwell, 2005, p.18).

\footnotetext{
${ }^{9}$ et-Tirmizî , Ebû Îsâ Muhammed b. Îsâ b. Sevre (Yezîd). Sünen-i Tirmizi Tercemesi. Çev. Abdullah Parliyan. 2. Cilt. İstanbul. Derya bask1, 2007.
} 
Free time can be expressed as the period of time when any job, school, game or sport ends. However, leisure and activity can be called types of social time, as different from work and as opposed to work. Free time belongs to private or family private space. This is not an inner purpose, it is an inner pastime, it is the sum of the activities that a person performs for himself. Therefore, free time is fun, free and not compulsory, it is personal work or at least personal choice (Slater, 2012, p.528).

If we evaluate the definitions of free time together; It is the time required for individuals to meet their basic needs and the time spent on these basic needs. And the freedom of the individual in his / her choices is that he / she prioritizes his / her characteristics in order to continue and increase the well-being process (Ardahan, Turgut, \& Kaplan Kalkan, 2016, p.8).

\section{Religion and Free Time}

Religion has a significant influence on people's behavior and activities. However, it has a profound effect on the individual's daily actions and activities as well as on group life (Sweedlun \& Crawford 1956, p.130). Religion is also about free time. It can be said that working time and free time are not clearly separated in modern society and religion is intertwined with free time. Religious forms have taken a large place mainly in social games, dances, festivals, rituals and songs (Tezcan, 1994, p.45-49). Free time activities have become more effective as a result of the institutionalization and secularization experienced by modern society (Fabian, 1999, p.21). However, modern man had more free time. However, religion functions as a way out for the modern man's lack of a goal and the negativities that will occur in the face of this aimlessness (Okumuş, 2005, pp. 59-61)

Today, when we look at issues such as the withdrawal of religion to private spheres, a situation such as privatization of religion and isolation from work and public sphere is perceived. This brings us to a situation where individuals go to places of worship such as mosques outside of their working hours. Considering these situations, it becomes clear that religion is also perceived as a leisure activity. Religion is tried to be captured in private areas. Religion, as a natural response to this situation, engages in the free time institution, and as a result of this, it engages in activities to make use of the free time of religious and non-religious 
people. Religious associations, foundations, communities or authorities carry out special activities in free times for the religious or inclined people. Trips, programs, conversations, conferences are among these activities. However, these activities are included in certain private places to worship. When we look at the functions of these activities, it can be said that they have many functions such as making people feel pleasure with the awareness of spending their time by gaining thawabs, reviving the sense of religiousness of people, connecting the person to the group, strengthening the bonds of the individual with the religious structure. And also, religiosity experienced in free times should be evaluated differently from compulsory religiosity. Because there is a voluntary basis in orientation to religion in free times. Islam gives importance to participating in social activities with contemplation and tranquility. It is seen in some hadiths and verses that people are praised to participate in society and help them solve their problems. While contemplation, worship and doing useful works for society are a religious duty, they also provide the spiritual satisfaction of modern people in their free time. If free time is not planned correctly, it can cause waste of time and lead to negative situations for individuals. Lack of free time and equal opportunities can also lead to social polarization and class conflicts (Okumuş, 2005, p. 32-65).

David Reisman states that in the modern period, free time has turned into an institution and the duty of this institution is used to make up for the shortcomings in other areas of society. The fact that free time has turned into an institution indicates that it has lost its function of gaining freedom and creativity. Reisman believes that by making the study more meaningful, all negativities about free time can be eliminated. However, Reisman sees that it is not possible to make working more meaningful, and that the working masses have to use their free time and consumerism to obtain the satisfaction and dignity received from them by the social order (Aydoğan, 1999, p. 195).

\section{The Sense of Leisure Time}

Leisure time; it refers to the time when an individual does not need compulsory work for a while and uses them according to their owm wishes (Karaküçük, 2005, p. 12). The etymology of the words "empty" and "time" should be considered separately. The word "empty" is a Turkish word and the oldest known usage is in the 9th century. It is used to mean unclaimed for "sheep". (Irk Bitig) he word "Free person (free person, freed)" is used in the 
meaning of freedom in Divan-1 Lugati't-Türk. However, its main meaning, "liberty and freedom", has become a connotation over time. There is not a single word in Turkish for leisure time or free time. However, the word "skhole" is used in Ancient Greek as a word that means both terms. (Sentuna 2010). The English equivalent of the word "leisure" means being free, and its Latin equivalent "licere" means being free from work (Aytaç, 1997).

The sense of leisure is discussed in two parts: "leisure before modernization" and "leisure after industrialization". In ancient times, in ancient Greek, leisure time, goodness, beauty, truth, knowledge were accepted as thinking about these values. According to this idea, leisure is not a period of time without any pursuit. On the contrary, it includes intellectual activities such as distinguished, aesthetic, beautiful and creative thinking (Gediz, 2012). Considering the leisure time after industrialization, it is observed that the working hours decreased in the early 1900s, especially as a result of the work done in the business world and administration (Uygur, 2007). Reduced working hours have resulted in an increase in people's free time (Odabaşı, 2009, p. 35).

Leisure time generally derives its origin from God's story of creating the world. This issue is expressed in the Bible as follows: "Heaven and earth are complete with all its elements. By the seventh day God finished what he was doing. He rested that day from his work. He blessed the seventh day. He has made it a holy day. Because, God rested and finished all the work he did and created that day." In this context, the term leisure is considered a sacred legacy, and the history of leisure is considered God's creation history. However, this issue is not handled in this way in the Quran. Surah Yunus in verse 3, "Undoubtedly, your Lord is Allah, who created the heavens and the earth in six days, and then (he created) the throne, who rules all things. There is no one to intercede unless he gives permission. This is Allah, your God, so serve him. Don't you think about them!" 10 in the form of revelation, God's need to rest was not mentioned. Leisure activities have a great influence on the physical, psychological and social virtues of individuals. Therefore, leisure time activities will also affect people's lifestyle (Ağaoğlu, 2012).

Many methods have been proposed to explain the concept of leisure time. Most of these methods emerged after the industrial revolution (Balc1 \& İlhan, 2006). The research of the

\footnotetext{
10 Yunus 103/3.
} 
American sociologist Thorstein Veblen explains the interconnection of leisure and social class. Weberian believed that leisure is the life of the bourgeoisie (Yetiş, 2008). Torkildsen expressed free time in four groups. These groups are as follows (Torkildsen, 2005, pp. 46-47):

a. Leisure Time as Time (Duration): In this definition, Torkildsen; It expresses not only the time spent to earn money, but also the time remaining from the time used to meet some basic needs (such as eating, sleeping) as leisure time.

b. Leisure Time as a Lifestyle: Aristotle expresses leisure time as time left over from compulsory labor and a way of life. For this reason, activities to be carried out in leisure time have a great impact on the lives of individuals and contribute to the different activities that exist in individuals' lives.

c. Leisure Time as an Activity: Rather than daily basic needs of people (physiological needs) and work life, they are the activities that an individual does within a certain period of time, all of which belong to the individual. These activities can be physical, mental and emotional activities.

d. Leisure Time as Recreation: While the terms recreation and leisure are intertwined according to some perspectives, they are two terms that complement each other but differ from each other according to a different perspective. In this case, leisure time refers to the time remaining after basic needs are met, and recreation refers to activities performed in leisure time.

\section{The Sense of Leisure Time in Islam}

Islamic religion; As stated in the Qur'an and the hadiths of the Prophet Muhammad (s.a.v), it does not allow time to be completely wasted. Verses 5 and 8 of Inshirah Surah provide important information for understanding leisure time in the Islamic context:

"So there is a convenience with the difficulty. Yes, there is a convenience with that difficulty. When you are idle (renounce), get tired immediately and demand your Allah".

The connection between the meanings of the words "renunciation" and "demand" in the verses is important. "Renunciation" means giving up something and turning to Allah by 
sacrificing and means to stop dealing with something or a job. In addition to the word, it also means turning towards something, an object, by sacrificing, refusing, not succumbing to the soul. In short, the Holy Quran; It is understood that he ordered the Prophet Muhammad and Muslim individuals to turn to God in their spare time, as well as to be useful to people and themselves, to be forgiving, tolerant, to act with the value of the time in their hands, to make their leisure time meaningful and meaningful ${ }^{11}$ (Okumuş, 2013, p. 122).

In the aforementioned Surah of Inshirah, it is stated that " ease will be achieved after difficulty " and then it is said 'then when you are empty, you get tired again". ${ }^{12}$ Elmalı Hamdi Yazır interprets this verse as follows: "When you get away from a task, a prayer, a job and become easy, it is also troublesome to fall into comfort because the job is over, and you get old for another worship, another job, work, get tired; If the obligatory is over, be in vain, if the prayer is over, go to prayer, it will increase with ease, thank God you have done a lot" (Yazır, 1960, p. 5925).

\section{It is possible to draw some important inferences from the verse and its}

\section{interpretations:}

1. According to the religion of Islam, free time is not a time to be wasted. In any case, time should not be wasted, time should be used when idle and a new job should be started. When he finishes dealing with people and matters of life, he must turn to Allah wholeheartedly. Verses on this subject are interpreted as starting a different job after completing an occupation, spending the time "full" rather than idle.

2. The social and personal aspects of human life and social and personal activities are mentioned in the verses. Considering the phrase "when you are empty" as the time after individuals have fulfilled their primary and essential duties, it is understood that this term refers to the social aspect of life. In addition to this social and social aspect, the individual dimension is also addressed with the term "tired". In other words, social duties and obligations should be fulfilled, on the one hand, and on the other hand, one should listen and contemplate individually. He should express his

\footnotetext{
11 Diyanet İşleri Başkanlığı (DİB)," Diyanet Tefsir" el-İnşirah 94/5,3.

12 el-İnşirah 94/7.
} 
gratitude in the face of the blessings Allah has given, perform the prayers that are his duty towards the creator, pray, rest and store energy.

3. One thing we can deduce from the verses is that rest is achieved by changing jobs. These verses show the way of working and resting. In terms of helping to understand leisure time in Islam, it is useful to examine the meaning of the Quran to world life. The Quran likens the worldly life to a game and entertainment:

"The life of the world is nothing more than a game (le 'ib) and linger (lehv). Surely the abode of the hereafter is better for the protected ones, don't you think? ".13

It is said in the verses that games and entertainment are temporary, just like games and entertainment, it is stated that the worldly life is also temporary. According to the understanding of the Islamic world, this life is the farm of the hereafter. Both sides will be won here. Therefore, the world is a place where the afterlife can be won. The world is not a place of laziness, negativity, but a place of activity and work. The religion of Islam is a religion that covers all spheres of human activity. Islam does not only care about the hereafter, but also happiness in the world. The fact that man was created as a caliph on earth and that other beings and blessings on earth serve people actually reveal the Islamic world view. According to the religion of Islam, life in the world is a garden and field of the other side, the hereafter. The belief of "Tawhid", which constitutes the essence of Islam, plays an important role in the point of view of the world. In line with this belief, Islam is a system of orders and behaviors that regulate human life, with its own holistic and inclusive qualities and principles, that is, individuals and society, materially and spiritually, in accordance with the Tawhid. The following Hadith will make an important contribution to the understanding of Islam's perspective on leisure time: "Know five things as opportunity and booty before five things arrive; The value of life before death, health before sickness, leisure before occupation, youth before old age, and wealth before poverty." ${ }^{14}$ (Okumuş, 2005, pp. 67-77). When it is said that Islam does not accept the aforementioned leisure time, it should not be concluded that it refuses to rest. It is stated that the 47th verse of the Surah Furkan and the 9th verse of the Naba are the most beneficial option to rest. It is stated in verse 23 of the chapter of Rum that both the night

\footnotetext{
13 el-En'am 6/32, Ankebut 29/64, Muhammed 47/36

14 Diyanet İşleri Başkanlığı (DİB), "hadislerleislam”.
} 
and the day can be chosen to sleep. In the 58th verse of Surat an-Nur, "qaullah", that is, sleep at noon is expressed. Hz. the Prophet (s.a.v) used to sleep at noon because he helped him get up for night worship. It is reported that he sleeps "qaullah" sleep before or after performing his prayer, depending on whether the weather is cold or hot. An-Nahl in the 80th verse; It is stated that "Allah has made your dwellings a place of peace and tranquility for you." It is understood from this verse that the place where a person can rest in the most comfortable and convenient way will be his own home ${ }^{15}$ (Canan, 1994, pp. 98-103).

\section{The Difference Between Free Time and Leisure Time}

It is seen that the senses of leisure time and free time are mostly accepted as the same concept and included in the same definition. However, there are dissimilarities between the terms "leisure" and "free". "Leisure time" in "free time" is the activities that an individual can choose freely. Many researchers point out that there are various differences between the senses of leisure time and free time. According to Garzia: "Every person may have free time, but not leisure time" (Karakük, 2008, pp. 29,31). "Leisure time" and "free time" are two different concepts, and their content is completely different functionally. Although they are intertwined, the meaning and expression phenomena they carry are completely different (Mannell \& IsoAhola, 1987). According to this; Leisure time is the time spent with specific activities and is a part of free time (Mieczkowski, 1990, p. 10). Free time is the remaining time from work (Göral, 2013, p.9). Leisure time is time spent outside of work (Argan, 2017, p.13). For example: 1 hour of a person's remaining time from work is free time. It is leisure time to eat 15 minutes in this 1 hour free time. According to Tezcan (1993, p.8-11), if a person goes to a place to eat or drink, it is not an activity but an obligation, but if he goes to a place to meet and share with a social environment, he eats, he defines it as a leisure activity. Activities other than nonwork obligations are considered as leisure time in research. Because it is undoubtedly a fact that every individual has physiological needs, the times when needs such as eating and sleeping are generally expressed as leisure time, and the times outside of these activities are considered as free time by many researchers (Karakoç \& Taydaş, 2013, p.35. ).

\footnotetext{
15 el-Furkan 25/47, en-Nebe 78/9, er-Rum 30/23, Nur 24/58, en-Nahl 16/80
} 


\section{Free time and leisure time representation is given in Figure 1.}

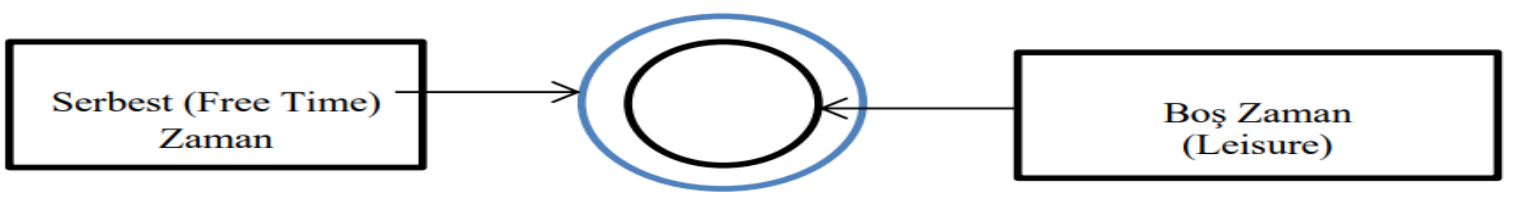

Figure 1. Contemporary Understanding of Leisure (Öztürk, 2018, p.35).

\section{Recreation}

The word recreation is derived from the Latin word "recreatio" and means "renewing, refreshing, restoring". Contemporary entertainment and cultural traditions have their roots in ancient cultural traditions and practices. Leisure and entertainment history benefits from various culture, arts, sports and entertainment activities, as well as diversified with religion, education and management elements (McLean, Hurd, \& Rogers, 2007, pp. 40-49). Turkish Language Society means "The activities that people participate voluntarily in their spare time for entertainment and sports purposes." and although he describes it as "making an area into a state where people can use it for recreation and entertainment"; It is understood that this recipe does not fully indicate both the brevity and the content of the word recreation. Although recreation is often referred to as "taking leisure time" (Karaküçük, 2008, p. 59), TLS (1994) stated that the most appropriate meaning of the term "recreation" is "recreational area"; but the meaning of the word "recreation" is not included in the "Guide for Foreign Words" of the TLS (http://sozluk.gov.tr/, access date: 25.11.2020). Recently, it is seen that it is rarely stated as "entertained" in scientific publications (Kocalar, 2013, 2016). Microsoft ${ }^{\circledR}$ Office Word program also corrects the word recreation as "recreational" in the spelling and grammar check. Recreation can be considered as an activity or experience of individuals, and individuals can freely choose their free time to satisfy their desires and participate voluntarily (Torkildsen, 2005, p.52). Leisure time and recreation are terms that have been handled together in the historical process. Individuals deal with different occupations in their leisure time; Since people have recognized the concept of "working" since the early ages, the phenomenon of leisure has continued and with the passage of time, recreational activities have been included in the concept of leisure (Gül, 2014). Recreation is a factor that ensures healthy development of individuals and society while choosing appropriate activities in their leisure time (Torkildsen, 
1992, pp. 66-67). Entertainment is actually a process of carefully choosing activities. (Miller and Robinson: 1963). Individuals need entertainment according to their social class due to personal, social, economic and environmental effects. The reasons why individuals and societies feel the need for recreation are personal physical health development, feeling mentally well, socializing, realizing and developing their talents, providing work discipline and increasing work efficiency, contributing to economy, feeling happy, etc. (Karaküçük, 2016, p. 80-93). The realization that recreation is to improve life rather than a complement to business life has been as follows: The increase in production with the technology of the 20th century increases the leisure time of the employees; Therefore, people realized that they need cultural, educational and communicative development individually and collectively. Thus, recreation was needed (Kılbaş-Köktaş, 2010, pp. 56-57). Recreation is related to the attitudes, psychological reactions and attitude of the people who perform the activities rather than being the reason for the activities (Torkildsen, 1992, p. 64). Recreation for people; In addition to expressing meanings such as regeneration, relaxation, revival, liberation, returning to the individual and self-awareness, self-expression, it also means friendship, integration with the team, sharing of experience, being a team, being a part of nature (Torkildsen, 2005, p.55).

The purpose of recreation applications is to be able to evaluate Maslow's need for selfactualization, which is at the top of the hierarchy of needs; one's goal is to meet one's own needs most strongly; One of the people's needs is the "need for self-realization", making people feel disappointed and unhappy, causing introverted and aggressive reactions; it can make the society unhappy (Karaküçük, 2016, pp. 76-77).

Karaküçük (2008, pp. 61-66) features of recreation: "Being chosen as a volunteer, giving a sense of freedom, not being obliged to attend and participate, being done in leisure time, no age and gender discrimination, having the initiative on the person, all kinds of indooroutdoor areas, seasons. and can be applied in climatic conditions; requires and includes physical, mental and / or spiritual activities, gives pleasure, is a source of reward and happiness for the individual, is applied universally, allows the individual to express himself and reveal his creativity, can have a different purpose for each individual, a recreation activity provides ground and opportunity for other recreational activities, recreation cannot be done by someone else for the individual, recreation is an experience, it comes out as a result of participation". $f$ 
we need to evaluate the definitions of recreation together; Recreation can also be expressed as "the totality of activities that people can enjoy in their free time, alone or with a group, and as a result they have fun, feel a refreshment, regeneration and enjoyment physically and spiritually" (Ardahan, Turgut, \& Kaplan Kalkan, 2016, p. 11).

\section{Recreation and Islam}

Entertainment activities that do not violate the basic principles of religion, belief and morality are acceptable, as long as the balance between the basic principles of belief and morality is maintained in terms of Islam. In this sense, as long as these activities are carried out in accordance with "Islamic rules", it can be accepted and even encouraged to be seen as recreation in Islam. As a matter of fact, the practices in this direction, it is possible to come across in the life and hadiths of the Almighty Prophet Hz. Muhammad (s.a.v). It is not possible for a person to work, sleep or pray in all time. The person will want to rest in line with his interests and possibilities and to do different activities from the things he has always done and the people he is with constantly. Thus, it is normal for him to want to develop and satisfy himself physically, spiritually, and mentally. This requires some leisure time. Leisure time takes on this role. In fact, this means that leisure activities, games, or recreational activities used for recreational purposes are not worshipers, but are an important source of energy, health, and motivation for people to worship more effectively. It may be accepted and encouraged to choose and apply any of the recreational activity groups, provided that they do not conflict with the basic principles of religion and are within the rules of Islamic morality and general ethics. The factor that needs to be known especially here is that if an assessment is made from an Islamic perspective, there must be a balance between the time devoted to recreational activities and the time a Muslim devotes to his prayers. In other words, recreational activities should not prevent prayers or worship should not be an alternative option. In addition, "Allah's approval" must be observed in all activities. The Islamic understanding always prioritizes the approval of Allah. Undoubtedly, an important condition stated by the basic sources of Islam, is that a Muslim can manage his time well with the formation of time consciousness. In this direction, it should be especially taken into consideration that the time to be devoted to working, worshiping, studying, sleeping, eating and drinking, and resting or leisure should be used in a planned and healthy way (Karaküçük, 2019, pp.112-113). 


\section{Sports in Islam}

Sport and religion are two phenomena rooted in human history. Sport, which is known to be as old as historical religion (Muhammed, 2001), has always had a relationship between religion and sports, as it has a religious aspect in its roots and spiritual elements in its nature (Coakley, 1998). Sports activities framed by religious elements are common in traditional societies. Since religion is a fundamental element of orienting life, various activities are of religious importance and sports-like activities gain legitimacy from religious references (Muhammed 2001). On the one hand, eating disorders occur in order to live a long life and enjoy the dominant life desire. As a result, the risk of obesity, malnutrition, alcohol, drug and tobacco use, sudden death and threatening human life is gradually increasing (Giddens, 2000). While doing all this, excessive exercise is also prohibited from the religious aspect and one can prevent them with sports.

It is believed that healthy living is a right given by Allah in the religion of Islam (Hergüner, 1993, p. 82). Islam sets rules to guide the various actions taken in every aspect of a person's life, from birth to death. Islam allows and encourages some sports activities that benefit people's education and activities within certain rules. There are rules as well as sports promotion. These rules are often not straightforward. The reason for this is that the concept of "sports" was not fully formed in the period when the Holy Quran was started to be downloaded. However, it is possible to find references to sports activities in verses and hadiths. So; Although the history of sports can be traced back to ancient times, it turned out that sports at that time were not classified and organized in a systematic way as they are today, which can be used as a reason why it is not in the Islamic literature. For example; Hz. the Prophet (s.a.v) recommends learning shooting, not as one of today's sports branches, but because it is useful and aimed at meeting the needs of that day. For this reason, we can see shooting as a "sport" title in hadith sources (Telkenaroğlu, 2011, p.74.).

As long as sports protect the basic principles and elements of Islam and do not lead to the neglect of worship and ethical duties, it is considered permissible. However, sports types and styles that lead to waste, gambling and bad habits are not considered permissible. ${ }^{16}$ Islam

\footnotetext{
${ }^{16}$ Diyanet İşleri Başkanlığı Yayınları (2006). Peygamberimiz’ in teşvik ettiği bazı sportif faaliyetler, İlmihal, c.2, s.117. Ankara. E.T. 28.11.2020
} 
promotes sports because it is essential for human health. Stating that "people do not know the value of two great blessings, health and leisure time" (Bukhârî, "Rikâk", 1) ${ }^{17}$, Hz. Muhammad (s.a.v) said that "a strong believer is better than a weak one" ${ }^{18}$ and advised to engage in sports (Iş̧k, 2013). When we look at the definiton of exercise and health, of course, it is not inconceivable that Hz. Muhammad (s.a.v) was not interested in sports and sports branches and did not advise people on this issue.

Hz. Muhammad's (s.a.v) sports advice is not only for health purposes, but also for entertainment, war, etc. It should not be overlooked that he does this in many different ways and makes suggestions on this issue. The main types of sports that Hz. the Prophet (s.a.v) personally practiced, encouraged, and clarified are as follows: Wrestling, running, racing, horse and camel races, swimming, shooting arrows, hunting, watching sports activities, doing sports activities individually or collectively, giving prizes to winners (Kuşçuzade, 2015, p. 398).

Provided that it does not conflict with the basic elements of religion, it can accept and encourage any sports activity as long as it remains within the morality of Islam and general moral rules. The fact that should be stated here is that when considering the path of Islam, the time devoted to recreational or sports activities should not interfere with the prayers and prayers of Muslims, that is, the scale of recreational activities should not be so large as to interrupt worship. In addition, the general purpose of all actions and activities should be Allah's consent. The priority of individuals should be to use the time given to them by Allah sparingly and economically. A Muslim individual should manage the time he devotes to worship, work, sports, science, sleep, in short, for all his activities (Karaküçük, 2019, p.113).

Hz. the Prophet (s.a.v) encouraged him by recommending "Muslims to walk, swim, shoot arrows, ride horses." He also participated in races that made all sports within certain times, sometimes became a spectator, sometimes raced or raced his horse and camel. Hz. the Prophet Muhammad (s.a.v), on the one hand, recommended sports activities for play and entertainment purposes and did so himself, as well as establishing an order for sports activities by establishing rules in terms of races, award distribution, organizations or fair play behaviors (Arslan, 2015, p.449.; cited in Karaküçük, 2019, p.145). These competitions are run under

\footnotetext{
${ }^{17}$ Diyanet İşleri Başkanlığı (DİB), "Diyanet webdosya"

18 İmam Muhyiddin Ebu Zekeriyya Yahya bin Şerefeddin Nevevi, Riyaz’us Salihin, çev. Mehmet Türk (İstanbul: Enes Matbaası, 2015), 64
} 
certain Islamic regulations and prizes are distributed within the framework of these regulations. Since the earliest times related to these mentioned areas, Islamic jurists have studied the Quran and Hz. Prophet's (s.a.v) Sunnah about sports and competitions. The rules imposed on the competition between humans and other living things continue to constitute the most modern and human aspects of sporting events. The main purpose in this regard should be that people do not harm each other, do not torture animals, do not hurt them, and avoid activities that will result in death or injury. As a matter of fact, hitting the face and head is considered haram according to Islamic Law. For this reason, boxing and some far east sports are deemed controversial in terms of Islam (Karaküçük, 2019, p.145-146).

\section{Recommended Sports in Islam}

Hz. the Prophet (s.a.v) himself did not ban sports in his life, even personally participated, encouraged and determined the principles of some sports. According to sources, these sports are track and field (running), wrestling, archery / shooting, swimming and horse riding. ${ }^{19}$ These branches, whose names are mentioned in the hadiths of the Messenger of Allah (saas), are clearly included. In addition to the branches above, the Messenger of Allah (s.a.v) passes by a group trying to lift a big rock from the ground to determine who is stronger, and this activity, which is approved with silence, is considered to be a circumcision of weightlifting since there is no bad side (Vecdi, 2012. , p. 8). What needs to be done here is to determine the benefits of these branches to people and compare them with today's sports types. In this case, it can be said that the most prominent common feature of the above branches is that they give people some personal or social needs such as strength, speed, endurance, defense and combat skills. Since Hz. the Prophet (s.a.v) wanted Muslims to acquire useful skills and abilities, he encouraged them to adopt the specified branches. In past Muslim societies, these demands of the Messenger of Allah (s.a.v) were highly valued and facilities were built for these sports aimed at providing entertainment and needs (İmamoğlu, 2018, p.907.)

During the time of the Prophet (s.a.v), a sport called "Dirkele" was played with a spear, and a sport called "Kurref", which can be called football, was played in Mecca and Medina (Turan, 1986, p.37; cited in Karaküçük, 2019, p.144). Not to prevent religious worship, not to

\footnotetext{
${ }^{19}$ Diyanet İşleri Başkanlığı Yayınları (2006). Peygamberimiz’ in teşvik ettiği bazı sportif faaliyetler, İlmihal, c.2, s.115. Ankara. E.T. 28.11.2020
} 
obstruct scientific research and professional research, not to cause personal or social damages during the implementation process, to engage in activities taking into account the consent of Allah at every stage of the application should be essential in sports. It is even a mandatory element. Taking these factors into consideration, any kind of sports activity can be considered worship for a Muslim. While Hz. the Prophet (s.a.v) always supported archery shooting, he sometimes participated in training groups and watched the matches, sometimes shot arrows, sometimes supported him, sometimes walked and controlled the route where the wrrow was shot. "Allah gives a favor to every step of the person who goes back and forth from where the arrow was shot and where it fell" , "Archery is not fun, archery is the best thing you have fun", and, "A father must teach his child how to write, shoot arrows and swim." (Kuşçuzade, 2015, p. 402). Caliph Hz. Umar by recalling the hadiths of the Prophet (s.a.v), he wanted everyone, including children, to do archery, riding, swimming, and running sports (Karaküçük, 2019, pp.145, 155).

Hz. the Prophet (s.a.v) encouraged Muslims to wrestle. The following is stated in the narration reported by Ibn Hisham: Rükâne Ibn Abdi Yazit, the famous wrestler of Mecca, suggests that Hz. the Prophet (s.a.v.) must wrestle and beat him in wrestling in order to accept Islam. Hz. The Prophet (s.a.v) accepts this condition and beats and wins the Rükâne who is good at wrestling (Abu Dawud, Libas 21). Hz. Abu Hurayra (radıyallâhu anh) narrates: "The Messenger of Allah (s.a.v) said:" There is a gift in these three things: camel race or horse race or arrow race. "(Abu Dawud, Jihad, 67). As you can see, Hz. Muhammad (s.a.v) suggested sports that he saw as beneficial (Kuşçuzade, 2015, p.398).

Hz. the Prophet (s.a.v) allowed and encouraged horse races to be organized, therefore, a special area was reserved and awards were given to the horses participating in the race. Hz. the Prophet (pbuh) participated in a race from Haifa, which is six miles away, to Seniyyetü'l-Veda, together with a well-trained horse. Hz. the Prophet Muhammad (s.a.v) also encouraged camel races like horses, occasionally organized camel races such as horse races, and even participated in races personally (Turan, 1986: 12; cited in Karaküçük, 2019, p.156).

Hz. the Prophet (s.a.v) made a running contest with his wife Hz. Aişe to keep her heart pleasing and set an example for the companions. Hz. Aişe won the match, but in the second race, Hz. Aişe got fat because a long time had passed over the first race and therefore lost the 
second race. In the race that Hz. Aişe lost, Hz. Muhammad (s.a.v) said to his wife, "This is the rematch of the previous race, now we are equal" (Turan, 1986: 12; cited in Karaküçük, 2019, p.22).

\section{Game}

The game, starting from childhood to old age, all people physically or mentally, alone or collectively, planned or not planned in free time; however, it is understood that it is a recreational activity because it is based on volunteerism criteria. The game is limited to the time people spend outside of the activities they spend in their daily lives, apart from the rules determined at a specific place and time according to their voluntary service, bilateral relations and emotional maturity. It is made with certain principles of its own in a certain time and place accompanied by physical and mental abilities, depends on the criteria of willingness, provides interpersonal communication and emotional maturity, based on skill, mindfulness, rational, influencing the people who watch as well as those who play, sometimes make people feel tension but they are activities that never provide financial benefit, pleasure and happiness (Şahin, 2005). Game, speed, perception of distance, coping with difficulties, solving problems, coordinating with other people, designing, etc. It is a learning environment that helps to acquire many skills and can benefit from learning many skills through experience and practice in order to apply a cognitively prepared lifestyle to real life (Sevinç, 2004). Game is an activity that has always existed in the lives of individuals in general. Participation in any game can be stated as a sincere desire or behavior. The game that does not require planning and decision before, and does not have a mental requirement; it is always an area dominated by uncertainty. It can be stated that games have an irrational structure due to this ambiguous structure. (Pilavc1, 2014). Synthesist theory states the main elements of the terms leisure and play as follows (Hazar, 2003):

A- Individuals get rid of stress by relieving by throwing out the excess energy accumulated in them in daily life through game.

B- $\quad$ Children get prepared for life by gaining experience about the problems they may encounter in the future through game. 
C- Leisure activities and game ensure that culture is passed down from generation to generation.

D- The game will help release repressed emotions and thus help people relax.

E- Individuals, through game, meet their need for success and appreciation, promotion of their personalities and respect.

F- The game ensures satisfaction of individuals by overcoming the rush of life and struggling with problems.

G- Since game includes life as well as physical needs, it benefits people, thus the modernization and development of society.

$\mathrm{H}$ - The urge to game creates changes by reflecting on the individual's attitudes and actions.

Sevinç states the contributions and benefits of game activities to children's body, emotional, social and cognitive development areas as follows; "He becomes excited and happy. His ability to imitate improves. His imagination expands. The process of getting used to real life is accelerated. He becomes an active individual by gaining self-confidence. He gains creativity and productivity. The ability to communicate with people increases. He spends more physical energy" (Sevinç, 2004) .

If we think in terms of children, they can indicate problem-solving skills, anger, love, happiness, likes or dislikes and many other emotional states with a game they play. He can establish a balance between himself and environmental conditions through games. Game is a tool for children to learn, it is an internal behavior. Since children do not have many opportunities to reach strong emotions, creating opportunities for children to play will be very beneficial to establish relationships with adults and remove the complexity they experience. Through games, children can gain instruction, concentration and curiosity skills in solving conflict problems, preparing for the future, adapting and in school life. (Adigüzel, 2013). 


\section{Religion and Game}

Islam wants the individual to be peaceful and happy throughout his life. Therefore, playing and having fun legitimately is seen as a natural requirement. Rest, games and entertainment in preventing religious duties are regarded as worship. When it comes to game, children come to mind directly. Playing games is an effective factor in the cognitive development and personality development of children and the emergence of their abilities. As understood from different narratives and rumors, in the time of the Prophet (s.a.v), children were played games such as swinging, walnut, ball, throwing a lover, steel stick, pinwheel, head, fiyal, lu'betü'd-dab (a kind of line game), shooting arrows. (TDV, 2018, pp.5,9)

\section{Game in the Quran}

The concept of the game in the Quran is generally used for adults. Deceptive, (Tevbe: 9/65; Maide: 5/57, 58; Enam: 6/70.), the thing that deviates life from its purpose (An'am: 6/32; Ankebut: 29/64; Muhammed; 47/36; Hadid ; 57/20.), and the life of the world that is worthless compared to other life (Anbiya: 21/55; Zuhruf: 43/83; Mearic: 70/42.). There is a verse in Surah Yusuf where the life of Hz. Yusuf is described. "They said:" O our father! Why do you not trust us about Yusuf? Yet we are the ones who want his goodness. Send him tomorrow with us (to the countryside) so that he can drink and play, we will definitely protect him. " Their father said, "Honestly, it worries me that you take him away; "I'm afraid that the wolf will eat it when you are not aware of it."20 When Hz. Yusuf asked permissin from his brothers' fathers to play games, it is seen that they stated that Hz. Yusuf was a child and needed to play game. It is understood that Hz. Yakub also deems this reason appropriate and therefore approves the game as a need for children. However, while giving permission, he expressed his concern for security. From here, it can be concluded that the playing place and tool should be designed considering the safety of children (Dodurgal1, 1998, p. 63).

When examining these verses, it should be understood that the verses with negative connotations are not related to educational games, children's games or useful games. Already when look at the life of the Prophet (s.a.v), it is understood that he allowed children to play game and also participated in their games. Hz. the Prophet (s.a.v) lived in accordance with the

\footnotetext{
${ }^{20}$ Yusuf 12/11-13
} 
Quran. $\mathrm{n}$ this case, it is determined that there is no negative or prohibitive verse about children playing in the Quran. Hz. Yakup, who was also a prophet, the fact that he gave permissin to Yusuf about the game shows that the religious game is not a prohibitive element. (Özen, 1999, p.114).

\section{Game in Sunnah and Hadiths}

Hz. Muhammad (s.a.v) was sent to all humanity as an educator and a leader. His great influence on the life of the society and his companions proves that he is a good educator. Looking at the examples of the game in the life of the Hz. Prophet (s.a.v) will be beneficial in this respect. When, Hz. Muhammad (s.a.v) was teaching people, he was understanding, giving importance to knowledge and choosing the best method he could tell the subject, and expressed it according to their age and level in a way that children could understand. A game in the sunnah of the Prophet (s.a.v), it included firsts such as complaince with the level, persistence, convenience, not being boring, making the child active and most importantly, doing it with love. Hz. the Prophet (s.a.v) was very affectionate, did not cause difficulties, liked to help, loved learners very much, and put a lot of effort into their work (Gudde, 2001, pp. 25-59).

Hz. the Prophet (s.a.v) took care of his grandchildren, sometimes taking them on his back and taking them around the house. When Câbir saw them in like that, "How beautiful is your camel!" what the Messenger of Allah said, "They are also beautiful riders." (İbn Asâkir, XIII, 216, 217). When Hz. Muhammad (s.a.v) saw the children playing games, he saluted them (Muslim, "Birr", 96-97) and joked with them. In fact, according to the narration of Anas, the person who joked with children the most was Hz. Muhammad (s.a.v) (Tabarani, II, 38). ${ }^{21} \mathrm{~Hz}$. the Prophet (s.a.v) tolerated children and games. Even the companions showed the same sensitivity and used games and toys in the education of children. Hz. Muhammad (s.a.v) played "azm-i vaddah" in his childhood. This game was played as follows: a piece of bone would be thrown in the dark and the one who found it would win the game. In this game, the losers had to carry the winners from where the bone was to where it was thrown (Özen, 1999, p. 121122). In some rumors, Hasan or Husayn, the Prophet (s.a.v) while leading the prayer, used to prostrate too much so that the children could get off of their own will. When asked the Prophet (s.a.v) why did prolong prostration because of revalation, he answered that my grandson was

${ }^{21}$ Diyanet İşleri Başkanlığı (DİB), "Diyanet webdosya" 
on my back and I did not finf it appropriate to hurry so that he would not fall off spontaneously (Ayhan, 1982, p.246). Many examples that cannot be counted on the subject can be expressed here. As can be seen, the Prophet Muhammad (s.a.v) played with the children about the game, accompanied them, played himself as a child and set an example by showing this to the companions. Games in Sunnahs, they are grouped under three headings as "purposeful games, distracting games, harmful games".

A. Purposeful Games: This type of games is a preparation for life, and both children and adults are encouraged. Horse Riding and Camel Races, Swimming, Walking and Running, Wrestling, Shooting, Hunting are included in this group.

B. Distracting Games: These games are games that allow children to have fun and all kinds of games that keep children entertained and entertained can be handled here, provided that they are not prohibited. Kurrek (Football), Fun with Animals, Chess, Night Talks are the games in this group.

C. Harmful Games: These games are gambling and betting games, which are also prohibited religiously. Games such as Gambling and Backgammon are included in this group (Author, 2015, pp. 117-131).

\section{CONSLUSION AND SUGGESTIONS}

Apart from the time devoted to working, a person sometimes needs to rest and to spend his or her favorite activities in all the hustle and bustle of life. While managing his time, he should be controlled at the point of working, resting, and doing the activities he likes. Islam gives importance to the use and management of one's time. For this reason, it is possible to find verses with content from time to time in the Quran. Because time is one of the most important blessings given to man. The religion of Islam does not prohibit people from doing sports and engaging in different activities as long as they do not follow the line of religion and general moral rules. In the study, the perspective of the religion of Islam to time, leisure time, recration and the point of view on sports was also examined with some examples from the life of $\mathrm{Hz}$. Muhammad (s.a.v). With the fact that every individual from childhood to old age is definitely 
intertwined with play in a period of his life, the subject of play and game according to Islam is also discussed. The work to be done under the title of Islam and sports, starting from the life of the Prophet Muhammad (s.a.v) and the life of the Eshab-1 Kiram (Companions), will show us the true place of sports in Islam. By increasing such studies, it can be prevented from the perception that there is a negative relationship between Islam and sports. Religion has the feature of encompassing and mobilizing society. The faculties of the study are not only Sport Sciences Faculties, but also Theology Faculties should be included in the studies in order to make this subject understandable. Activities to be carried out should be done to all elements of the society (children, young people, adults and old people) regardless of gender. The Presidency of Religious Affairs, which is another side of the issue, can assist in reaching all segments of the society through Friday sermons and sermons by religious officials. From this point of view, the part of religious discourse related to sports should be structured in a way that creates awareness by the society in the formation of healthy generations in all dimensions and information activities can be carried out by the officials. In addition, as a continuation of this study, it can be suggested to examine recreation in terms of theology, that is to reveal the importance of recreation in terms of other religions.

\section{REFERENCES}

Adıgüzel, Ö. (2013). Eğitimde yaratıcı drama. Ankara: Pegem Yayınları

Ağaoğlu, Y. (2012). Dershaneye devam eden üniversite öğrencilerinin okuma nedenlerinin ve serbest zaman etkinliklerine katılımlarının değerlendirilmesi. Spor ve Performans Araştırmaları Dergisi, 3(1), 33-41.

Akatay, A. (2003). Örgütlerde Zaman Yönetimi, Selçuk Üniversitesi, Sosyal Bilimler Enstitüsü Dergisi, Sayı: 10.

Akseki, H. (1960). İslam dini. Ankara: Diyanet İşleri Bakanlığı Yayınları

Ardahan, F., Turgut, T. ve Kaplan Kalkan, A. (2016). Her yönüyle rekreasyon. Ankara.

Argan, M. (2007). Ĕglence pazarlaması. Ankara: Detay Yayıncılık

Arslantürk, Z. (2014). Din sosyolojisi din sosyolojisinin 'Nedir? 'liği, İstanbul: Çamlıca Yayınları.

Atay, H. (1974). Fârâbî ve İbn Sina'ya göre yaratma, Ankara: AÜF Yay

Aydoğan, F. (1999). Modern dönemde serbest zaman ve medya. Doktora Tezi. Marmara Üniversitesi, Sosyal Bilimler Enstitüsü, İstanbul.

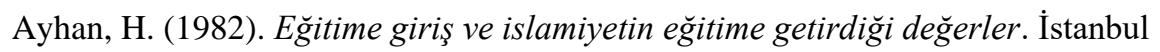

Aytaç, Ö. (1997). Modern toplumda boş zaman olgusu. Dünya' da ve Türkiye’ de sosyolojik gelişmeler. (1. Baskı). Ankara: Sosyoloji Derneği Yayınları. 
Ayyıldız, T. (2015). Rekreatif dans faaliyetlerine katılan bireylerin serbest zaman tatmin düzeylerinin incelenmesi. Yüksek Lisans Tezi. Gazi Üniversitesi, Sağlık Bilimleri Enstitüsü, Ankara

Balc1, A. (1990). Zaman yönetimi. Ankara Üniversitesi, Ĕ̈itim Bilimleri Fakültesi Dergisi, Cilt:23, Sayı:1.

Bilmen, Ö. N. (1972). Muvazzah ilmi kelam, İstanbul: Bilmen Yayınevi.

Caldwell, L. L. (2005). Leisure and health: why is leisure therapeutic?". British Journal of Guidance \& Counselling, 33(1), 7-26.

Canan, İ. (1994). Vakti en iyi değerlendirme esasları, İslam'da zaman tanzimi, İstanbul: Cihan Yayınları.

Canan, İ. (2008). İslam'da zaman tanzimi. Işık Akademi Yayınları.

Coakley, J.J. (1986). Sport in Society, Issues and Controversies, Santa Clara, College Publishing.

Deniz, M. (1996). Etkin zaman yönetimi ve Türkiye'deki büyük tekstil işletmelerindeki uygulaması. Doktora Tezi, İnönü Üniversitesi Sosyal Bilimler Enstitüsü, Malatya.

DİB, Diyanet İşleri Başkanlığı, “Diyanet hadislerleislam” $\quad$ E.T $14 \quad$ Aralık 2020. https://hadislerleislam.diyanet.gov.tr/pdf/index.php?DERGI=hadislerle_islam_cilt1.pdf

DİB, Diyanet İşleri Başkanlığı, “Diyanet hadislerleislam” $\quad$ E.T $14 \quad$ Aralık 2020. https://hadislerleislam.diyanet.gov.tr/sayfa.php?CILT=1\&SAYFA=335\&SRC=be\%C5\%9F\%20\%C5\%9F ey

DIBB, Diyanet Işsleri Başkanlı̆̆l, "Diyanet $\quad$ webdosya”. $\quad$ E.T $14 \quad$ Aralık 2020. https://webdosya.diyanet.gov.tr/hadis/UserFiles/Document/riyazussalihin_cild_1.pdf

DIB,$\quad$ Diyanet İşleri $\quad$ Başkanlığ,$\quad$ "https://dergi.diyanet.gov.tr/". $\quad$ E.T $\quad 14 \quad$ Aralık 2020. https://dergi.diyanet.gov.tr/makaledetay.php?ID=9690

DIBB, Diyanet Işsleri Başkanlı̆̆l. "Diyanet $\quad$ webdosya". $\quad$ E.T $14 \quad$ Aralık 2020. https://webdosya.diyanet.gov.tr/hadis/UserFiles/Document/riyazussalihin_cild 3.pdf

DİB, Diyanet Işleri Başkanlığl. "Diyanet webdosya”. E.T $14 \quad$ Aralık 2020. https://webdosyasp.diyanet.gov.tr/muftuluk/UserFiles/istanbul/UserFiles/Files/Din\%20ve\%20Hayat\%20D ergisi\%20Say\%C4\%B1\%2036\%20Y\%C4\%B11\%202018\%20\%200yun\%20ve\%20E\%C4\%9Flence 950a85c2-3c81-4550-8e09-6104cc412449.pdf

Diyanet İşleri Başkanlı̆̆l (DIB). ” Diyanet Tefsir”. Erişim 15 Aralık 2020. https://kuran.diyanet.gov.tr/Tefsir/

Diyanet İşleri Başkanlığı Yayınları (2006). Peygamberimiz’ in teşvik ettiği bazı sportif faaliyetler, İlmihal, c.2, s.117. Ankara

Dodurgalı, A. (1998). Ailede çocuğun din ĕgitimi. (2. Baskı). İstanbul: İFAV Yayınları.

Efendi, M. A. (1755-1820). El-okyânûsu'l-basît fî tercemeti'l-kâmûsi'l-muhît kâmûsu'l-muhît tercümesi. http://ekitap.yek.gov.tr/urun/el-okyan\%C3\%BBsu-l-basit-fi-tercemeti-1-kam\%C3\%BBsi-l-muhit--takim6-cilt-_536.aspx E.T. 29.11.2020.

Elias, N. (2000). Zaman üzerine (Çev: Veysel Atayman). İstanbul: Ayrıntı Yay.

et-Tirmizî , Ebû Îsâ Muhammed b. Îsâ b. Sevre (Yezîd). Sünen-i Tirmizi. Çev. Abdullah Parllyan. (İstanbul. Derya baskl, 2007), "Zühd” 24 (No.2332)

Fabian, J. (1999). Zaman ve öteki. (Çev. S. Budak). Ankara 
Gediz, S. (2012). Kamu hizmeti olarak rekreasyon etkinlikleri kapsamında gençlik hizmetleri ve spor il müdürlükleri batı akdeniz bölgesi gençlik merkezleri analizi. Yüksek Lisans Tezi. Akdeniz Üniversitesi, Sosyal Bilimler Enstitüsü, Antalya.

Giddens A. (2000). Sosyoloji. İstanbul: İnsan Yayınları.

Göral, Ş. (2013). Internet ortamında geçirilen boş zamanın üniversite ögrencilerinin mutluluk ve yaşam doyum değerlerine etkisi. Gazi Üniversitesi, Sağlık Bilimleri Enstitüsü, Ankara.

Gudde, A. E. (2001). Bir ĕgitimci olarak Hz. Muhammed (s.a.v.) ve öğretim metodu, Enbiya Yıldırım (çev.), İstanbul: Yasin Yayınevi, s.59.

Gül, T. (2014). Rekreasyon olgusuna genel yaklaşım. (Editör: A. Yaylı). Rekreasyona Giriş. Ankara: Detay Yayıncilik.

Han, V. (1989). Bilim ve uygarlık açısından İslam. İstanbul: İşaret Yayınları.

Hardal, İ. M. (2012). Bir din felsefesi problemi olarak zaman - kişilik ilişkisi. Yüksek Lisans Tezi. Dokuz Eylül Üniversitesi, Sosyal Bilimler Enstitüsü, İzmir.

Haynes, M.E. (1999). Kişisel zaman yönetimi. (Çeviren: Y. Bülbül). (1. Baskı). İstanbul: Alfa Basım Yayım Dağıtım

Hazar, A. (2003). Rekreasyon ve animasyon. Ankara: Detay Yayınc1lık

Hergüner, G. (1993). Kadınların spor yapmalarını etkileyen sosyo-kültürel faktörler (Samsun ili uygulaması). Yüksek Lisans Tezi, Marmara Üniversitesi, Sağl1k Bilimleri Enstitüsü, İstanbul

Işık, H. (2013). İslam dini açısından spor ve hapkido. http://www.altunbasspor.com/makalelermainmenu-47/23teknik-bilgiler/99-lam-d-asindan-spor-ve-hapko.html E.T. 15.12.2020

İmamoğlu, O., Çebi, M., İslamoğlu, İ. ve Yamak, B. (2018). Osmanlı İmparatorluğunda spor tekkeleri ve kulüpleşme. Uluslararası Sosyal Araştırmalar Dergisi, 11(58), 907-912.

Josephs, R. (1996). Zaman yönetimi. (Çeviren: Özlem Koşar) (2. Baskı). İstanbul:Epsilon Yayınları.

Karakoç, E. ve Taydaş, O. (2013). Bir serbest zaman etkinliği olarak üniversite öğrencilerinin internet kullanımı ile yalnızlık arasındaki ilişki: Cumhuriyet Üniversitesi örneği. Selçuk İletişim, 7(4), 33-45.

Karaküçük S. (2005). Rekreasyon boş zamanları değerlendirme. Ankara.

Karaküçük, S. (2008). Rekreasyon: Boş zamanları değerlendirme. (6. Basım). Ankara: Gazi Kitabevi.

Karaküçük, S. (2016). Rekreasyon bilimi. (S. Karaküçük, Editör). Ankara: Gazi Kitabevi.

Karaküçük, S. (2019). Boş zaman rekreasyon ve İslamiyet. Ankara: Gazi Kitabevi.

Karslı, M. D. (2004). Sınıfta öğrenme zamanının yönetimi. Sıııf Yönetimi. (Editör: M. Şişman ve S. Turan). Ankara: Pegem A Yayıncilık.

Kılbaş-Köktaş, Ş. (2010). Rekreasyon: Boş zamanı değerlendirme. Ankara: Gazi Kitapevi.

Kocalar, A. C. (2013). Sivas kızılırmak havzasında eğlendinlen alanları yaratma denemeleri. II. Rekreasyon Araştırmaları Kongresi, Kuşadası, Aydın.

Kocalar, A. C. (2016). Klyı şeridi eğlen-dinlen alan düzenlemeleri ve mevcut kullanım örnekleri (Mersin). Birinci Kent Estetiği Sempozyumu Bildirler Kitabı. Samsun Büyükşehir Belediyesi Kültür Yayınları No: 29. 
Koch, R. (1998), The 80/20 Principle: The Secret of Achieving More With Less, Bantam Doubleday Dell Publishing Group, New York.

Kur'ân Yolu Meâli, Hazırlayanlar. Hayrettin Karaman-Mustafa Çağrıcı-İbrahim Kafi Dönmez- Sadrettin Gümüş. Ankara: Diyanet İşleri Başkanlığı Yayınları, 8. Basım, 2018

Kuşçuzade, M. (2015). Sünnette spor. International Journal of Sport Culture and Science, 3(Special Issue 4), 396403.

Lee, J. H., Scott, D. ve Floyd, M. F. (2001). Structural inequalities in outdoor recreation participation: A multiple hierarchy stratification perspective. Journal of Leisure Research, 33(4).

MacKenzie, R. A. (1989), Zaman Tuzağı: Zamanı Nasıl Denetlersiniz?, (Çeviren: Yakut Güneri). İstanbul: Amacom İlgi Yayınları.

Mannell, R. C. ve Iso-Ahola, S. (1987). Psychological Nature Of Leisure And Tourism Experience. Annals Of Tourism Research, 14(3).

Mansuroğlu, S. (2002). Akdeniz üniversitesi öğrencilerinin serbest zaman özellikleri ve dış mekan rekreasyon eğilimlerinin belirlenmesi. Akdeniz Üniversitesi Ziraat Fakültesi Dergisi, 15(2).

McLean, D. D., Hurd, A. R. ve Rogers, N. B. (2007). Kraus' recreation and leisure in Modern society. Massachusetts: Jones and Bartlett Publishers.

Merdin, S. (1998). Tanrlya Koan Fizik, İstanbul: Tima Yayınları

Mieczkowski, Z. (1990). World Trends in Tourism and Recreation. New York: Peter Lang Publishing.

Miller, N. P. ve Robinson, D. M. (1963). The leisure age: its challenge to recreation. Belmont, CA.: Wadsworth Publishing Company

Muhaddis, "muhaddis.org" $\quad$ E.T $14 \quad$ Aralı $2020 . \quad$ http://muhaddis.org/cgibin/dbman/db.cgi? db=ks\&uid=default \&view_records $=1 \& \mathrm{SNo}=* \& \mathrm{nh}=484$

Muhammed, G. (2001). Spor ve kültürünün kutsal kaynaklarl. İstanbul: İnsan Yayınlar1.

Nebi, M. (1991). Kur’an-1 Kerim mucizesi, Ankara: TDV Yayınları

Odabaşı Y. (2009). Tüketim kültürü. (3. Basım) İstanbul: Sistem Yayıncılık.

Okumuş, E. (2005). Eskişehir'de boş zaman kültürü. Proje Çalışması, Eskişehir, Osman Gazi Üniversitesi BAPKB

Okumuş, E. (2013). Odunpazarı evleri’nde ramazan gecelerinde boş zaman mekanları. Eskişehir Osmangazi Üniversitesi Sosyal Bilimler Dergisi, 14 (Özel Sayl).

Omay, U. (2008). Boş zamanın manipülasyonu ve çalışma. “İş, Güç” Endüstri İlişkileri ve İnsan Kaynakları Dergisi Cilt:10 Sayl:3 , Temmuz 2008, ISSN: 1303-2860

Özen, M. (1999). Íslam eğitimcilerinden bazılarına göre çocukta oyun ve oyuncak, Yayınlanmamış Yüksek Lisans Tezi, Marmara Üniversitesi Sosyal Bilimler Enstitüsü, İstanbul.

Öztürk, Y. (2018). Boş Zaman, rekreasyon ve turizm kavramları arasındaki ilişkinin karşılaştırmalı bir analizi. Sosyal, Beşerî ve İdari Bilimler Dergisi, 2.

Pasl1, E. (2019). Kur'an'da zaman kavramı ve" An" Yüksek Lisans Tezi. Necmettin Erbakan Üniversitesi, Sosyal Bilimler Enstitüsü. Konya. 
Pilavcı, G. (2014). “Oyun” kavramı ve mimari tasarıma kattı̆̆ farklı boyutlar: Oyun alanları ve oyun mekânları üzerine bir inceleme. Yayınlanmamış Yüksek Lisans Tezi. Mimar Sinan Güzel Sanatlar Üniversitesi, Fen Bilimleri Enstitüsü, İstanbul

Scoot, M. (1997). Zaman yönetimi. İstanbul: Rota Yayınları.

Sevinç, M. (2004). Erken çocuk gelişimi ve eğitiminde oyun. İstanbul: Morpa Kültür Yayınları

Slater, D. (2012). Çalışma/Boş zaman. Chris Jenks (ed.), Temel Sosyolojik Dikotomiler içinde (ss. 528-544), çev. İhsan Çapcıŏlu, Ankara: Birleşik Yayınevi

Smythe, J. A. ve Robertson I. T. (1999). On The Relationship Between Time Management and Time Estimation, British Journal of Psychology, Vol:90.

Sweedlun, V. S. ve Crawford, G. M. (1956). Man in Society, C. 1, USA

Şahin, M.H. (2005). Beden eğitimi ve spor sözlüğü. İstanbul: Morpa Kültür Yayınları.

Şentuna, B. (2010). Boş zamanlar sosyolojisi,. İstanbul Üniversitesi Açık Ve Uzaktan Eğitim Fakültesi.

TDV. (2018). Din ve hayat, İstanbul Müftülüğü Dergisi, Y1l 11, Sayı 36. İstanbul

Telkenaroğlu, M. R. (2011). İslam ceza hukukunda hukuka uygunluk nedeni olarak spor faaliyetleri, Atatürk Üniversitesi İlahiyat Fakültesi Dergisi, Erzurum, sy.36.

Tengilimoğlu, D., Tutar, H., Altınöz, M., Öztürk Başpınar, N. ve Erdönmez, C. (2003). Zaman yönetimi. (Editör: Hasan Tutar). Ankara: Nobet Yayın Dağıtım.

Tezcan, M. (1993). Boş zamanlar sosyolojisi. Ankara: Ankara Üniversitesi Eğitim Bilimleri Fakültesi Yayınları.

Topal, N. (2009). Derste zaman yönetimi: Illköğretim 3. sınıf hayat bilgisi dersine yönelik bir inceleme. Yayımlanmamış Yüksek Lisans Tezi. Çukurova Üniversitesi, Sosyal Bilimler Enstitüsü, Adana.

Torkildsen, G. (1992). Leisure and recreation management. (Third Edition). London: Spon.

Torkildsen, G. (2005). Leisure and recreation management. (Beşinci bask1). London and New York: Routledge, Taylor and Francis Group.

Tunç, A. (2000). Osmanlı devletinde spor (Okçuluk) Yüksek Lisans Tezi. Niğde Üniversitesi, Sosyal Bilimler Enstitüsü, Niğde.

Tümer, G. K. (1997). Abdurrahman, dinler tarihi. Ankara: Ocak Yayınları.

Uygur, A. (2007). Yönetim ve organizasyon. (2. Baskı). Ankara: Nobel Yayın Dağıtım.

Yahya bin Şerefeddin Nevevi İmam Muhyiddin Ebu Zekeriyya, Riyaz'us Salihin, çev. Mehmet Türk İstanbul: Enes Matbaas1, 2015

Yaman, Ç., Türkmen, M., ve Hergüner, G. (2012). Gençlik Ve Spor İl Müdürlerinin Zaman Kullanım Olanak Ve Tutumlarının Değerlendirilmesi. Uluslararası Hakemli Akademik Sosyal Bilimler Dergisi, 2(3), 164-221

Yazar, S. (2015). Kur'an'da lehv, la'ib ve lă̆v kavramlarl. Yüksek Lisans Tezi. Uludağ Üniversitesi Sosyal Bilimler Enstitüsü, Temel İslam Bilimleri Anabilim Dalı, Tefsir Bilim Dalı. Bursa.

Yazır, E. H. (1960). Hak Dini Kur'an Dili. İstanbul.

Yılmaz, A. ve Aslan, S. (2002). Örgütsel zaman yönetimi, Çukurova Üniversitesi, İktisadi ve İdari Bilimler Dergisi, Cilt 3, Sayı 1. 